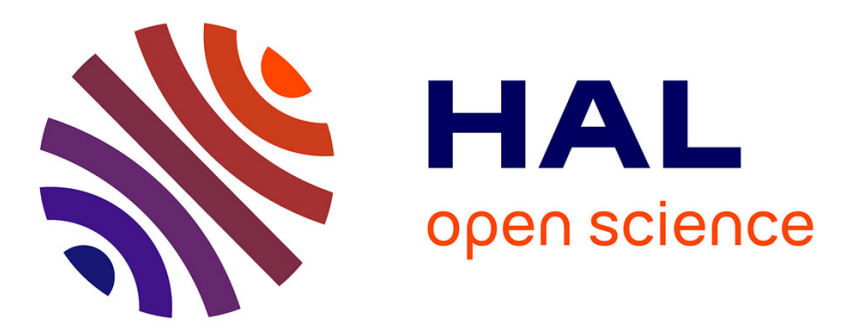

\title{
The logistics dualization in question: Evidence from the Paris metropolitan area
}

\author{
Adeline Heitz
}

\section{To cite this version:}

Adeline Heitz. The logistics dualization in question: Evidence from the Paris metropolitan area. Cities, 2021, 119, pp.103407. 10.1016/j.cities.2021.103407 . hal-03323061

\section{HAL Id: hal-03323061 \\ https://hal.science/hal-03323061}

Submitted on 20 Aug 2021

HAL is a multi-disciplinary open access archive for the deposit and dissemination of scientific research documents, whether they are published or not. The documents may come from teaching and research institutions in France or abroad, or from public or private research centers.
L'archive ouverte pluridisciplinaire HAL, est destinée au dépôt et à la diffusion de documents scientifiques de niveau recherche, publiés ou non, émanant des établissements d'enseignement et de recherche français ou étrangers, des laboratoires publics ou privés. 


\title{
The logistics dualization in question: Evidence from the Paris metropolitan area
}

\author{
Adeline Heitz \\ CNAM Paris (French Institute for Research and Long-Life Higher Education), Lirsa Laboratory \\ (Interdisciplinary Research Center in Action-oriented Sciences), France
}

Article published in Cities 119 (2021) 1034070264-2751

\begin{abstract}
We examine the logistics dualization in the Paris metropolitan area using a database revealing the stock of logistics facilities. By introducing a new typology of logistics facilities, we are able to call into question the idea of a logistics dualism. We identify a third segment of the logistics real estate market, which is neither suburban nor urban. The existence of intermediate logistics facilities demonstrates that the metropolitan logistics landscape is more complex than a simple dual structure suggests. Our analyses highlight the mechanisms of the logistics real estate market, the role of public policy, and issues related to the development of metropolitan areas.
\end{abstract}

\section{Introduction}

In recent years, the location of logistics activities in metropolitan areas has been examined in the research fields of geography, urban planning and regional sciences. Two major trends have been identified. Part of the literature has focused on the development of suburban logistics and logistic sprawl (e.g. Bowen, 2008; Cidell, 2011; Rakotonarivo \& Dablanc, 2010), thus making it possible to show the contribution of ordinary activity to metropolization (e.g. Hesse, 2004, 2008). Another part of the literature deals mainly with urban logistics and in particular, the location of new logistics buildings in densely populated areas. Urban logistics is a service contributing to the optimization of urban distribution, providing innovative solutions to companies while respecting environmental and social conditions (Dablanc, Morganti, et al., 2017; Dablanc, Zeting, et al., 2017). Urban and suburban logistics are the result of these two spatial trends: concentration and dispersion, two antagonistic spatial dynamics that co-exist in metropolitan areas. The result is a dualism in the logistics real estate market, which has been identified in several metropolitan areas around the world (Rodrigue \& Berhends, 2018; Heitz, 2017).

It is difficult to assess from the literature what these two segments represent as shares in a real estate market in a metropolitan area. Indeed, it does not provide information on the existing logistics real estate stock or other types of logistics facilities that may exist. In this paper, we will analyze the logistics real estate stock in the Paris Region to evaluate the shares of urban and suburban logistics. We make use here of a database that reveals the existing stock of logistics facilities, and develop a new typology of logistics facilities, on the basis of which we call into question the logistics dualism. In doing so, we identify a third segment of the logistics real estate market, which is neither suburban nor urban. Intermediate logistics demonstrate that the metropolitan logistics landscape is more complex than a simple dual structure suggests. Here we study intermediate logistics and its trajectory in order to call into question the logistics dualism. Our analysis of a declining of intermediate logistics facilities in the Paris region suggests that "logistics dualization" is a process that tends to exacerbate the urban and 
suburban logistics real estate market more than a logistics dualism. Moreover, the method used to distinguish intermediate logistics from urban and suburban logistics invites us to call into question the perception of "urban logistics" and to go beyond the criteria usually used in the literature to define it.

We first present a literature review regarding the principal dynamics of the logistics real estate market (Section 2). Then we describe the data and methods we have used to analyze this market in the Paris Region. From these data we build a typology of municipalities based on their density and logistics profile (Section 3). We go on to analyze suburban and urban logistics as the dominant modes of production of logistics facilities and intermediate logistics (Section 4). In Section 5, we analyze the trajectory of intermediate logistics and discuss "logistics dualization". We present our conclusions in Section 6 which generate key knowledge to better manage the development of logistics facilities in metropolitan areas.

\section{The location of logistics facilities - from logistics sprawl to urban logistics: a literature review}

\subsection{Logistics sprawl and suburban logistics facilities}

Logistics sprawl means that logistics facilities gradually relocate to suburban areas, and this goes together with a growth in the number and size of new facilities. This section describes both the process of suburbanization and the characteristics of the warehouses resulting from this spatial dynamics. First, the literature has focused on factors that explain logistics sprawl from an urban planning or geographical perspective (Aljohani \& Thompson, 2016; Heitz, Launay, \& Beziat, 2017; Masson \& Petiot, 2012; Merenne-Schoumaker, 2011; Strale, 2013). Logistics facilities have developed in suburban areas close to major highway junctions or major transport infrastructure such as airports (Hesse, 2002; Cidell, 2011; Leigh \& Hoelger, 2012; Allen, Browne, \& Cherrett, 2012; Giuliano \& Kang, 2018; Sakai, Beziat, \& Heitz, 2020), providing ready access to the densely-settled area to deliver goods, as well as being accessible to the suppliers of goods. In peripheral and rural areas there is more land available and prices are lower than in the denser parts of the metropolitan area. Indeed, in the Paris Region we observed a gradient from center to periphery for land prices. Urban density is usually employed as a proxy for estimating this gradient (Rodrigue, Dablanc, \& Giuliano, 2017) since there is no specific data on the cost of land and logistics real estate, or on pricing in relation to logistics activities.

Endogenous factors also play a role in logistics decentralization. Urban renewal and changes in land use regulations in the dense parts of metropolitan areas tend to create a less favorable environment for logistics facilities. Demand for housing and new tertiary activities (offices, retail facilities) is increasing, warehouses become less desirable than other buildings. In addition, they generate different types of pollution (visual, noise, $\mathrm{CO} 2$ emissions), so are best not located near residential areas. Instead, they tend to be located to peripheral areas. Public authorities produce plans and regulations that influence the location of logistics facilities; they also grant building permits and create logistics zones to attract logistics facilities to their municipalities (Merenne- Schoumaker, 2011). Public authorities and logistics land developers therefore prefer to encourage the construction of logistics facilities in low-density areas, avoiding the additional costs arising from proximity to densely populated areas. Logistics suburbanization can also be explained by changes in supply chains. This trend began in the 1980s with the outsourcing of logistics and the emergence of third party logistics (3PL): logistics services providers (Hesse \& Rodrigue, 2004). Shippers consequently needed less spaces dedicated to storage. At the same time, 3PLs and carriers (transport operators) created a demand for a new type of facility: distribution centers that are larger single-storey, standardized facilities, from $10,000 \mathrm{~m} 2$ to 
$100,000 \mathrm{~m} 2$ and well connected to the road network (Cidell, 2010; Hesse, 2008). Thus, the location of these buildings results in a trade-off between a center of gravity between consumers, concentrated in dense metropolitan areas, and suppliers scattered along fragmented global supply chains, and available land able to host large sized buildings. Suburban areas meet all these criteria. The margins of metropolitan areas, which offer more affordable and available land, have over a period of thirty to forty years experienced the construction of a growing number of these facilities. Most recently, the demand for large facilities has been boosted by e-commerce shippers and mass retail stakeholders. Ecommerce and mass retail sectors are also the main driver for multi-storey warehouse demand and automated facilities, in the literature illustrated by Amazon's facilities. XXL warehouses which can reach150,000 $\mathrm{m}^{2}$ have recorded a significant increase worldwide since 2015 (JLL, 2019). When considering the various sectors the literature on suburban logistics emphasizes e-commerce, mass retail distribution, logistics services providers and transport operators. Some sectors, for example wholesale trade or industrial logistics, are not investigated. Suburbanization can also be explained by changes in demand for logistics real estate (Hesse, 2008). Since the 1980s, logistics operators have entrusted the construction of their buildings to real estate developers. Their objective is to create a supply of logistics real estate that meets the changing needs of logistics operators (adaptability, automation, adequate space, modern equipment) together with profitable real estate assets. Logistics facilities have become a source of income and a real estate asset that account for an increasing share of investors' portfolios (Fender \& Fender, 2015). Hesse (2004) and Raimbault (2014) show that the emergence of a logistics real estate market and dedicated private stakeholders (P3 Logistics Parks, Logicor, Logistis, Prologis, Segro, Goodman (Fender \& Fender, 2015)) seeking financial profit have greatly facilitated the suburban development of logistics. Given the low rate of productivity of logistics activities per $\mathrm{m} 2$, logistics real estate developers used to propose ever-larger facilities to benefit from economies of scale, constructing large standardized warehouses. Standards for cell sizes (about $6000 \mathrm{~m} 2$ ), fire safety, or automation determine the size and the architecture of a facility based on functionalist principles. The new standards have also rendered obsolete a large proportion of the logistics real estate in the Paris region, mostly in the former industrial suburbs.

\subsection{Urban logistics development: a new real estate market for logistics facilities in dense city centers}

At the other end of the spectrum we note the emergence of urban logistics in the literature. To limit the negative impact of freight transportation in urban areas (CO2 emissions, NOx emissions, traffic accidents), some researchers have proposed ways of optimizing urban logistics and transport activities (Allen, Thorne, \& Browne, 2007; Taniguchi, Thompson, \& Yamada, 1999). This concept is also known as "city logistics", and has prompted public authorities and private stake-holders to invest in a new type of logistics facility for dense city centers in which a modal shift to cargo-bikes or electric vans is possible. This movement is generally thought to be the opposite of logistics sprawl and a "return to the city center" for logistics (Diziain, Dablanc, \& Ripert, 2012; Taniguchi et al., 1999). Overall, the literature on urban logistics focuses on the facilities that host activities (consolidation, picking, lastmile deliveries) dedicated to the urban distribution and are located in dense city-center. Consequently, most of the studied urban logistics facilities are either Urban Consolidation Centers (UCCs), logistics hostels or urban warehouses. Some research has described the rise of a new logistics real estate market in multi-storey urban consolidation centers (UCC) (Browne, Sweet, Woodburn, \& Allen, 2005; Diziain et al., 2012; Browne \& Ryan, 2011; Trentini, Gonzalez Feliu, \& Malh' en' e, 2015), also discussing their feasibility (Leonardi, Browne, \& Allen, 2012; Marcucci \& Danielis, 2007; Olsson \& Woxenius, 2014). A UCC is a logistics facility "situated in relatively close proximity to the geographic area that it 
serves be that a city center, an entire town or a specific site (e.g. shopping center), from which consolidated deliveries are carried out within that area" (Browne et al., 2005). Deliveries involving cargo-cycles or electric vehicles can be made from these facilities. UCCs first emerged in the early 2000s and are similar to small cross-dock facilities, and are mostly used by parcel industry operators. They quickly became a new topic in the literature and subject to controversy with regard to funding, feasibility and efficiency. Logistics facilities often need to be adapted for city center development, and this usually entails additional costs. Real estate developers compensate for the cost of land by introducing activities that have a high rate of return per square meter. In many cases, public policies have provided subsidies or land for the construction of these facilities, something that casts doubt on the sustainability of this kind of public investment (Browne et al., 2005; Kin, Verlinde, van Lier, \& Macharis, 2015). After two decades of experiments and a mixed set of results, UCCs have prompted the discussion of "city logistics utopias that have not materialized" (Dablanc, 2018).

Logistics hostels are a second type of urban logistics facilities found in the literature. They integrate logistics activities in buildings where they can coexist with other activities (housing, offices, retail), resulting in a functional mix within the building. Some experiments have been made and most of them are in Paris and developed by Sogaris a semi- public company; few of them have been reported in the academic literature (Dablanc, Morganti, et al., 2017; Dablanc, Zeting, et al., 2017). Unlike the UCC, we have no available discussion for this new type of facility.

As we mentioned above, e-commerce is a powerful driver for the development of the logistics real estate market. Demand for small or medium facilities located in densely settled metropolitan areas that can store and process goods for "instant deliveries" or "ultra-fast delivery services" has recently increased significantly (Dablanc, Morganti, et al., 2017; Giuliano \& Kang, 2018). On the supply side, many online retailers' "spin-off" platforms offering instant delivery services have emerged in the market, for example Amazon Prime Now, Walmart Jet.com and Alibaba Hema (Jin, Simchi-Levi, Wang, Wang, \& Yang, 2019). Proximity to the consumer is central for this service; urban warehouses are dedicated to storing items that have the highest turnover or fresh food that can be delivered in $1 \mathrm{~h}$. They are dedicated to the delivery for the parcels industry and are operated by shippers (e-retailers) or carriers. The development of urban logistics is related to changes in consumer preferences, the rise of e-commerce and strategies built around services to the consumer that go beyond the simple provision of a good. Such urban warehouses are not planned or funded by public policy, and represent a nascent demand (CBRE, 2020). The challenge for public policy is to support this new trend, regulating and integrating logistics facilities into local planning regulations to forestall safety risks, pollution, rendering them compatible with the other functions of the city. The rise of the urban warehouse marks a turning point in city logistics with regard to the role of public authorities, which move from project leader to facilitator through planning and regulation. Today, urban warehouses stimulate the logistics real estate market.

We also note that those building are designed to fit urban fabric and adapt to the existing environment according mixed-use urban planning, whether it is a new building or the renovation of an existing one. Urban logistics is the result of a concept in urban planning, which generates new trade-offs to organize activities in the city.

\subsection{The limitations of literature on logistics facilities and logistics dualism}

Reviewing what the literature describes as suburban and urban logistics, we observe two clearly differentiated types of facility that serve different purposes and reveal two different segments of the logistics real estate market. Each of them has specific features. There is on the one hand a suburban 
real estate market which satisfies the interests of real estate investors and the supply chain management of shippers and carriers. These suburban logistics facilities are large, standardized buildings and cover all sectors (distribution, industrial logistics, mass retail logistics). On the other, there is a nascent urban logistics real estate market in densely populated areas covering a limited number of sectors (e.g. e- commerce, the parcels industry and in some cases the wholesale food trade). These urban facilities are small and tailor-made buildings that fit into densely settled areas and are compatible with other functions of the city.

The literature on the location of logistics facilities shows that a dualism exists in the spatial organization of logistics in metropolitan areas. Research focuses either on logistics sprawl and suburban logistics facilities, or on "city logistics" and specific urban logistics facilities; less frequently on both sets. Logistics dualism therefore involves the existence of two co-existing types of logistics facilities and "very different functional and operational characteristics" (Rodrigue \& Berhends, 2018). Suburban logistics and urban logistics thus reflect the usual distinction made between center and periphery in metropolitan areas. In their paper, Rodrigue and Berhends (2018) seek to demonstrate that the difference between urban and suburban logistics is not only attributable to urban density (a morphological criterion) but also to function. Thus, urban and suburban logistics would serve different functions at different scales. Urban logistics is said to be aimed at the "last mile" of urban distribution, while suburban logistics also serves national and international flows. Therefore, urban logistics is not only defined by a morphological criterion (urban density), but also by a functional one (urban distribution). This approach simplifies the representation of the logistics geography in metro areas. The literature review illustrates the fact that many factors explain the location of logistics facilities (i.e. availability of land and prices, public policies, logistics costs). Therefore, distinguishing urban logistics from suburban logistics could be more complex and needs to be questioned through empirical analysis. In this paper, we will show that the morphological criterion and the functional criterion based on the origin and destination of flows are not sufficient and can be contradictory.

Another limit in the literature on the location of logistics facilities, is that it focuses on spatial dynamics (sprawl or (re)development in the city center), which means that it mainly analyzes new logistics facilities. The literature on logistics sprawl has highlighted the scale of logistics suburbanization, but has not always evaluated the existing stock of facilities (Heitz, Launay, \& Beziat, 2018). Nor has it systematically investigated the development of this process and the impact of this new real estate market on the spatial organization of logistics activities. The literature on urban logistics rarely presents the subject from a real estate market perspective, but rather from urban experiments carried out by private or public stakeholders (Dablanc, Morganti, et al., 2017; Dablanc, Zeting, et al., 2017). Consequently, it is difficult to assess from the literature what these two segments represent as shares in a real estate market in a metropolitan area. In addition, the literature does not give us any information on the existing logistics real estate stock and other logistics facilities that may exist. In this paper, we will analyze the logistics real estate stock in the Paris Region to evaluate the shares of urban and suburban logistics.

Nevertheless, in trying to distinguish one from the other in the database we use in this paper (see next section), we realized that this distinction was not easy. We encountered several difficulties: 1 ) what is the limit to determine urban from suburban density? 2) How can we apply the functional criterion? 3) Are these criteria effective to classify logistics facilities between urban and suburban? 


\section{Data for the evaluation of the logistics real estate market, and recent changes to that market in the Paris metropolitan area}

\subsection{Data}

As mentioned above, the literature mostly assigns logistics facilities to one of two categories (urban and suburban facilities). Here we pro-pose a different typology to reveal a third type of logistics facilities, i.e. intermediate logistics facilities. In this paper, we have used the "Recensement Regional des Bâtiments Logistiques en lle-de-France" database (hereafter referred to as RRBL). The way in which the database has been constructed is discussed in two previous papers (Heitz et al., 2017: Heitz et al., 2018). The RRBL combines two data sources: the economic establishment files that the literature generally uses to identify the location of logistics facilities classified according the European classification of economic activities (NACE); and the French Warehouse List (Répertoire des Entrepôts), which identifies warehouses of more than $5000 \mathrm{~m}^{2}$. To this, we have added systematic fieldwork and the use of street photographs. The resulting data collection allows us to identify all logistics facilities through geocoding. The RRBL database includes 1629 logistics facilities. For each facility, we know the size (m2), the number of employees, the exact location, and the type of activity. We classified these facilities according to sector (e-commerce, industrial logistics, mass retail logistics, and logistics service providers). The RRBL allows us to analyze all of the logistics facilities, even those under $5000 \mathrm{~m}^{2}$, and to determine the sector to which each facility belongs. These data allow us to make a more accurate assessment of the current stock of logistics real estate.

To complete our database we evaluate the dynamic of the real estate market in these seven zones. The RRBL only covers one year (2016) and does not provide any information about changes. In addition, we decided to use the "Sitadel" database created by INSEE, which contains every building permit for residential or commercial buildings, including logistics facilities from the 1980s through to 2017, aggregated by municipality. In this paper, we shall focus on the most recent period, from 2008 to 2017, after the subprime financial crisis, to capture recent changes. This means that we analyze the cumulative area of logistics facilities constructed between 2008 and 2017. Given the very different nature of the Sitadel database and RRBL, it is not possible to crosscheck the information.

To consolidate our results and observations we conducted a series of confidential interviews with transport and logistics operators, as well as logistics real estate providers and public authorities in the Paris region. We interviewed ten carriers, fifteen shippers and four developers between 2016 and 2018. We also interviewed Sogaris, a semi-private company dedicated to urban logistics projects, and delegates from the City of Paris, Greater Paris and the lle-de-France region. The conclusions we were able to draw from these interviews for the most part coincide with the main features of the locational trends we observed through the quantitative analysis. They also contributed to our closing discussion in Section 6.

\subsection{Method: typology}

Conducting our fieldwork and consolidating the RRBL database, we observed a great variety and heterogeneity in logistics facilities. Identifying suburban from urban logistics facilities is not always obvious considering the morphological or functional criterion. We did not accompany the census (RRBL) with a systematic survey on all the 1629 facilities, which limited the information we were able to obtain on occupants and flows. However, conducting the fieldwork, we observed several small buildings located in dense areas, which are either serving goods at local and national scale which we 
wanted to investigate more. They correspond to old logistics facilities, made invisible in the dataset of Sitadel, which evaluates the warehouse flow rather than the stock. In order to distinguish them, we choose to build a typology of logistics facilities in the Paris region based on urban characteristics (morphology, urban density) that we used to distinguish urban from suburban logistics. We have used a classification of municipalities put forward by the Ile-de-France region ${ }^{1}$ that combines a measure of the degree of urbanization (surface area of buildings in the municipality), a measure of the population density, and criteria based on the type of urban area. This classification provides a morphological approach to municipalities and gives us a qualitative description of municipalities that goes beyond a mere density gradient. We cross-referenced the RRBL database with these seven categories to classify the logistics facilities according to type of urban fabric. We obtain from this a classification of logistics facilities according to urban density and the characteristics of the buildings (see Table 1).

Then we conducted an additional survey on the 331 logistics facilities (class 1 and class 2) combining fieldwork and interviews with the occupants to understand this segment of the logistics real estate market. We choose to focus on these two classes because they are the one identified as "urban areas" so where we could supposedly find urban logistics. This survey allows us two observe two more criteria: the logistics sector and the physical characteristics of the building.

To determine logistics sector we used the RRBL and classified facilities according to nine logistics meta-categories: Food wholesale trade (FOOD), Industrial wholesale trade (WIND), consumer goods wholesale trade (WCGO), logistics service providers (LSP), transport (TRAN), e-commerce (ECOM), industrial logistics (INDL), the parcel delivery industry (PARC), and mass retail distribution (MASS) ${ }^{2}$ (see Fig. 2). The sectors allow us to make the hypothesis that some of them are more likely to be related to urban distribution (e.g. parcel's delivery facilities or food wholesale trade facilities). We chose to consider the rest of the facilities as undetermined as to the origin or destination of the flows, except for the 331 facilities that we surveyed and that provided us with solid information.

To determine physical characteristics, we looked at the type of buildings (architecture, size, age, modern/dilapidated) which is relevant from a real estate market perspective since warehouses are real estate assets whose value on the financial markets also depends on the intrinsic characteristics of the property. The physical criteria allow us to distinguish new facilities designed specifically for urban logistics from those located from before, probably inherited from industrial period that may be used as urban logistics facilities. We also conducted fieldwork and the analysis of street view photographs in 2016, 2018 and 2019 to complement the RRBL database with qualitative information. The resulting database provides information about the type of facility (old/new, dilapidated/modern standards, shape, and architecture) which, combined with the size, gives us some idea of its age. For example, a $10,000 \mathrm{~m}^{2}$ facility that is occupied by a logistics service provider is assumed to be recent (built after 2000). A $3000 \mathrm{~m} 2$ facility occupied by a company providing a transport and storage service is assumed to be fairly old (built between about 1970 and 1990). The age attributed to buildings gives us a general idea of the state of the logistics real estate market in the Paris Region. Following the literature and interviews we assume that a building smaller that $5000 \mathrm{~m} 2$ is old and does not meet modern standards, except in the case of urban logistics.

The typology allows us to distinguish urban from suburban logistics facilities and to identify a third type of facility based on two additional criteria: logistics and physical characteristics.

\section{Three segments in the logistics real estate market}

\footnotetext{
1 "Découpage morphologique de l'lle-de-France", 2014, http://data.ilede france.fr.

2 Data in the RRBL database proposed by Heitz et al. (2017) are classified into 22 categories; we choose to group some of them in order to obtain a smaller number of categories
} 


\subsection{Geography of the logistics real estate market in the Paris region}

As we explained, we proposed a typology of municipalities according urban and logistics profile. Class 1 corresponds to municipalities with a high urban density and a small number of logistics facilities $(1,3 \%$ of the total). Class 2 corresponds to suburbs, densely populated with $18,9 \%$ of the logistics facilities (in number) but which represents only $8 \%$ of the cumulative areas. Class 3 to 6 represents suburban municipalities with a gradient of low population density and respectively $41.2 \%, 24,1 \%, 5.9 \%$, and $4.6 \%$ of the total of logistics facilities. These suburban municipalities concentrate most of the logistics facilities and the cumulative areas. Class 6 corresponds to rural areas where there is a small number of logistics facilities (3,5\%). The Fig. 1(a) and (b) illustrate the geography of logistics facilities in the Paris Region. Fig. 1(a) shows the location of the logistics facilities according the size of the facility and the density classification. Fig. 2(b) shows the cumulative surface area between 2008 and 2017 build in the seven zones previously identified.

Fig. 2 shows the repartition of the logistics facilities according nine different logistics sectors. We note that Class 1 presents a large pro-portion of parcel's delivery facilities (30\%) compared to the other. Class 1, 2 and 3 present a large share of wholesale trade facilities. Class 3 to 7 present a large part of LSPS facilities. All of them contain a large part of transport companies' facilities, which is not relevant to discriminate the different class. Class 1 appears apart from the others. Class 2 and 3 have similar profile except for the share of LSPS, and class 3 to 7 are quite homogenous.

Table 1. Typology of the facilities according the urban and logistics profile

\begin{tabular}{|c|c|c|c|c|c|c|c|}
\hline Class & $\begin{array}{c}\text { Density of } \\
\text { population } \\
\text { Inhabitant/ha }\end{array}$ & $\begin{array}{c}\text { Degree of } \\
\text { urbanization }^{2} \\
(\%)\end{array}$ & $\begin{array}{c}\text { Number of } \\
\text { warehouses }^{4}\end{array}$ & $\begin{array}{c}\text { Share of the } \\
\text { number of } \\
\text { warehouses }^{3} \\
(\%)\end{array}$ & $\begin{array}{l}\text { Average size } \\
\text { of the } \\
\text { warehouses } \\
\quad\left(\mathrm{m}^{2}\right)\end{array}$ & $\begin{array}{c}\text { Cumulative } \\
\text { area }^{5} \\
\left(\mathrm{~m}^{2}\right)\end{array}$ & $\begin{array}{c}\text { Share of } \\
\text { cumulative } \\
\text { area }^{4}(\%)\end{array}$ \\
\hline Cl. 1 & 300 & $>95$ & 22 & 1.3 & 4700 & 138,615 & 1.9 \\
\hline Cl. 2 & 100 & $>80$ & 309 & 18.9 & 6600 & 578,647 & 8 \\
\hline Cl. 3 & 30 & $>65$ & 678 & 41.2 & 7500 & $1,296,497$ & 17.9 \\
\hline $\mathrm{Cl} .4$ & $<30$ & $<65$ & 392 & 24.1 & 12800 & $2,289,796$ & 31.7 \\
\hline $\mathrm{Cl} .5$ & $<30$ & $<65$ & 96 & 5.9 & 13100 & $1,043,788$ & 14.4 \\
\hline $\mathrm{Cl} .6$ & $<30$ & $<65$ & 74 & 4.6 & 16500 & 856,589 & 11.9 \\
\hline Cl. 7 & $<30$ & $<65$ & 58 & 3.5 & 15500 & $1,024,259$ & 14.2 \\
\hline
\end{tabular}

Figure 1. Typology of the municipalities according to the INSEE classification and location of logistics facilities in 2017 (a) and cumulative surface area of logistics facilities built between 2008 and 2017 (b).

\footnotetext{
${ }^{3}$ The information come from the Découpage morphologique d'Ile-de-France", 2014

${ }^{4}$ The information come from the RRBL database. 2016

${ }^{5}$ The information come from the Sitadel database. 2015
} 


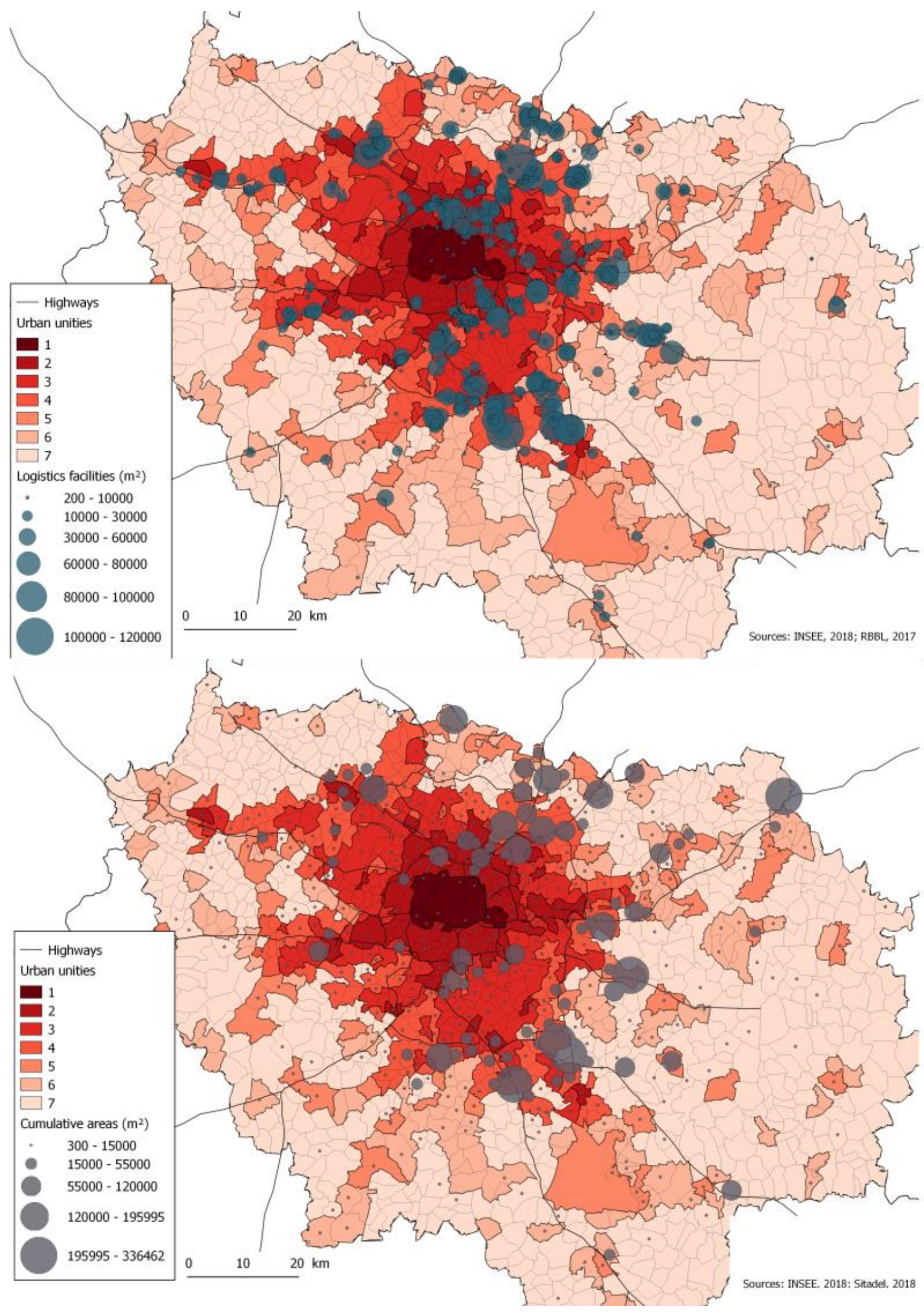


Figure 2. Distribution of logistics facilities according logistics sectors

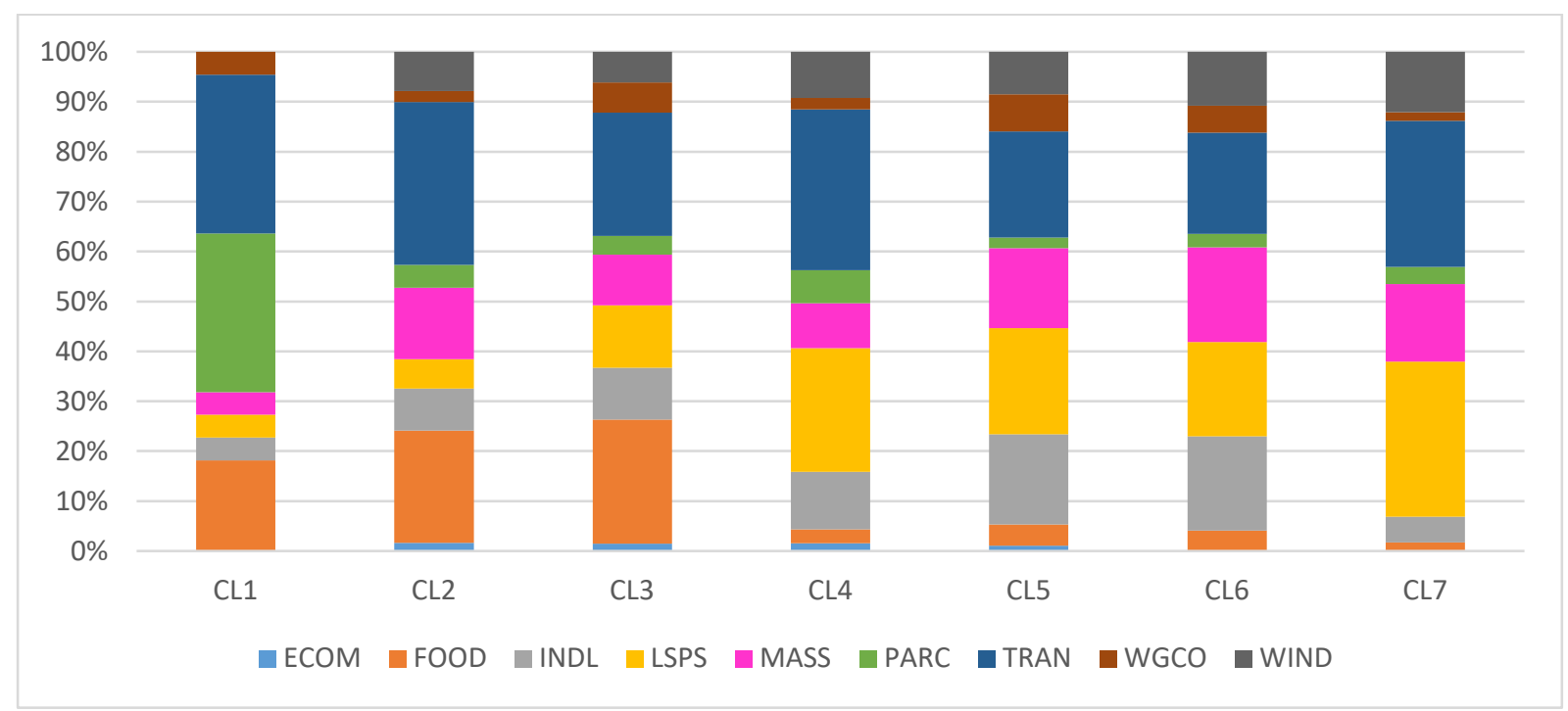

\subsection{In the dual system: the dominance of suburban logistics over urban logistics}

Roughly, $75 \%$ of logistics facilities are located in suburban areas considering the number of logistics facilities in class 3 to 6 (see Table 1). Suburban logistics is dominant in the Paris region, with $75.9 \%$ of the cumulative surface area of logistics facilities built between 2008 and 2017 being located in areas classed as 3 to 6 . The suburban area has municipalities with low population density, and consequently they are attractive to logistics real estate developers. We estimate that there was a total of 4,191,469m2 of suburban warehouse construction between 2008 and 2017, with suburban areas the main location for logistics facilities. The development of urban logistics does not limit logistics suburbanization as some public policies might have considered in a first place (Debrie \& Heitz, 2017). Observing each class individually, we note that Class 3 contains $41.2 \%$ of the logistics facilities, with an average size of $7523 \mathrm{~m} 2$ and $17.9 \%$ of the cumulative area. More than 1 million $\mathrm{m} 2$ of logistics facilities have been built in Class 3 areas. The Rungis wholesale market is in a Class 3 location, which may explain the presence of so many facilities owned by food companies $(27 \%)$ and the small average size of the buildings (less than $10,000 \mathrm{~m}^{2}$ ) - the warehouses occupied by the food sector in the Rungis market are fairly small, which is a specific feature of the sector. Lastly, we observe the presence of logistics facilities belonging to the wholesale trading sector and logistics service, as well as to transport and logistics operators. Class 3 is a mixed, medium-density area that combines new logistics facilities belonging to logistics service providers and longstanding logistics facilities clustered around logistics zones (e.g. Rungis and Garonor) or transport infrastructure (the Ports of Bonneuil or Gennevilliers). Class 4 municipalities contain $24.1 \%$ of the logistics facilities, whose average size is high at over $10,000 \mathrm{~m} 2$. This is the class of municipalities where the construction of warehouses has been the highest $(2,289,796 \mathrm{~m} 2$ between 2008 and 2017). Some major transport infrastructure is located in these municipalities, e.g. Charles- de-Gaulle Airport, one of the most important hubs in the region and in Europe. As in Class 4, in Class 5 areas logistics service providers' facilities are dominant compared to other sectors (25\%). Warehouses are slightly larger (about 13,000m2) and these municipalities have seen a high number of new constructions, which make up $856,589 \mathrm{~m} 2$ of a total of $1,043,788 \mathrm{~m} 2$. Class 6 contains logistics facilities with the highest average size (about $16,000 \mathrm{~m} 2$ ) related to logistics service providers, the mass retail distribution sector and industrial logistics. These sectors require large facilities and choose to locate in remote areas on the edge of rural areas. All suburban logistics facilities 
are mainly dedicated to these sectors. The logistics facilities located in rural areas are located in those municipalities with the lowest population density. Land prices here are the lowest in the region, which can be attractive to logistics real estate developers. However, while less than $3.5 \%$ of logistics facilities are located in these municipalities, there has been significant growth in the construction of facilities of more than 1 million $\mathrm{m} 2$. The facilities in these municipalities mainly belong to industry $(17 \%)$ and logistics service providers (31\%). Logistics facilities are not necessarily located in the less denselysettled part of the Paris metropolitan area, in fact they are mostly found in areas with a medium level of urbanization or density, and which are integrated within the Paris conurbation. Density and proximity are the two variables that determine the location of a warehouse in relation to its sector.

A dual logistics system does not mean a balanced system. There is an imbalance between the two types of logistics in the Paris metropolitan area: between the dominant suburban logistics real estate market and the emerging urban logistics real estate market. We also note the importance of sectors such as industrial logistics, wholesale trade or transport that are underrepresented in the academic literature on the location of logistics facilities. However, urban logistics as defined in the literature remains a smaller entity compared with suburban logistics.

\subsection{The "intermediate logistics facilities" and the logistics dualism}

If suburban and rural logistics represent about $80 \%$ of the logistics facilities, then in a dual system urban logistics should represent $20 \%$. Analyzing the results from the typology, we note that the densest area (Class 1) contains very few logistics facilities (1.3\%) and has experienced little warehouse construction (1.9\% of the regional cumulative areas of logistics facilities, i.e. about $140,000 \mathrm{~m} 2$ ). This class contains the city of Paris and some of the densest municipalities close to it. Class 2 contains $18.9 \%$ of logistics facilities. As one would expect, the average size of the buildings is lower than in other parts of the region (less than $5000 \mathrm{~m} 2$ ). As in class 1, the municipalities in class 2 experienced little construction of logistics facilities between 2008 and 2017, which indicates that it represents an unattractive area (about 580,000m2, $8 \%$ of the cumulative total area built in the Paris Region). Land prices could also explain this low degree of attractiveness. Proximity to Paris and high density limit the development of logistics facilities. According to the morphological criterion, facilities located in the densest part of the metropolitan area (class 1 and 2) should be considered to be urban logistics facilities. Facilities in class 1 and class 2 also differ by sector (see Fig. 2). The former are mainly related to parcel delivery, making up about $30 \%$ of logistics facilities against $2 \%$ of the facilities located in class 2. As a reminder, we made the hypothesis that some sectors were more likely to be oriented towards urban distribution (e.g. parcel's industry or wholesale trade). Those two sectors represent $55 \%$ in class $1,32 \%$ in class 2 , and $35 \%$ in class 3 . So, we could consider that facilities in class 2 are less oriented towards urban distribution than in class 1 . It is important to note, that despite the hypothesis we made here, most urban logistics facilities have an inbound goods traffic coming either from larger suburban warehouse or national distribution centers further away, and thus their business practice contains both types of transport movements. Consequently, facilities located in class 2 , are not necessary dedicated to urban distribution.

Using the grey literature, interviews with logistics real estate providers, public authorities and fieldwork, we investigated all the urban logistics facilities located in class 1 . We propose to present here some examples. The Beaugrenelle or Concorde UCCs developed in 2013 for the parcel industry operator Chronopost are $3000 \mathrm{~m} 2$ facilities and are the units that recur most often in case studies (Dablanc, Morganti, et al., 2017; Dablanc, Zeting, et al., 2017). We also recorded one logistics hostel, developed by Sogaris in Paris in 2018. This facility is a $42,000 \mathrm{~m} 2$ facility that includes an urban rail 
terminal for small containers and a UCC. Amazon has built one urban warehouse in the Paris 18th arrondissement (class 1 ) to provide instant deliveries. The company also developed a facility in the port of Bonneuil, close to Paris (Class 3 ) in a logistics zone, to meet the growing demand for this service. Ikea also built an urban warehouse in the port of Gennevilliers (class 3). Most of these projects are related to the parcel industry or e-commerce, and involve modern buildings. They are located either in class 1 or 3 . In class 2 , mass retail distribution represent about $10 \%$ of facilities, while wholesale trade represents $30 \%$ (food, industrial and goods wholesale trade) of these facilities. By comparison, mass retail distribution or in-dustrial logistics are also sectors represented in suburban areas. In some ways, the logistics characteristics of the class 2 facilities are more comparable to class 3 than class 1 . Facilities located in class 2 are more diverse than in class 1 and not only dedicated to urban distribution. Therefore, the functional criterion to distinguish urban from suburban logistics is to call into question.

As we mentioned in Section 3, we investigated the 331 facilities located in Class 1 and Class 2 areas through fieldwork, interviews with logistics real estate developers and logistics operators who are users of the facilities. We established that about $65 \%$ of them are old, usually built before 2000 . They are also small single-storey buildings of between $200 \mathrm{~m} 2$ and $5000 \mathrm{~m} 2$ with ridged roofs, as opposed to the flat roof of modern standardized buildings. Ceiling heights and the layout of the buildings (with for example few non-elevated dock doors) do not meet the modern standards characteristic of the latest generation of buildings (mostly suburban facilities) (DTZ, 2011). Their external appearance, tends to mislead urban planners and public authorities, who mistake them for manufacturing sites, artisanal or commercial activities, and sometimes, vacant buildings. It is important to emphasize that a dilapidated building is not necessarily a sign of lack of economic profitability or missing integration into a wider global distribution network, as many subcontractors for bigger companies. But, as subcontractors they also dependent of very competitive market. Our survey reveals that many of them struggle to gain market shares. The aspect of the building could also be a sign of lack of investment due to high expenses (e.g. rent or Cities 119 (2021) 1034077taxes) and fluctuating profitability. Some of the manager we interviewed during our survey mentioned this difficulty.

Considering those specific characteristics, we propose to group those facilities in a distinct category: intermediate logistics facilities. It brings new perspectives on urban logistics, often perceived as modern, tailor- made, designed to meet modern standards and fit into the urban fabric as we observe in the literature review. Intermediate logistics facilities are the blind spot of the urban logistics policies and could appear as "de facto" urban logistics facilities when the rest of them are at the crossroads of coordinated action by private logistics players and the public authorities' urban planning objectives.

\section{The trajectory of intermediate logistics facilities}

\subsection{Urban context and real estate market trends: maintaining logistics activity in a competitive environment}

Intermediate logistics firms are mostly located in the former industrial suburbs, which are undergoing major urban development and are subject to the dynamics of gentrification. Their proximity to Paris has made these suburbs a strategic area that is attractive for new service activities and to population. These inner suburbs contain a large pro-portion of the office buildings of the lle-de-France region (Nappi-Choulet, Maleyre, \& Maury, 2007). Combined with deindustrialization, a decrease in the number of factories, the suburbs gradually became an extension of the city of Paris. The profitability of office real estate has led to local public policy that encourages the private sector to accommodate tertiary activities. The municipalities in question rely on this type of investment to stimulate their 
employment development policy. Given urban pressure, the spatial dynamics and public policy, the intermediate logistics sector faces issues and call into questions if it seeks to remain in this dense part of the metropolitan area.

To measure this competition we have used the "Sitadel" building- permit database we described in Section 2. We consider the cumulative total area of the facilities built between 2008 and 2017. This data is available for each municipality, and has been aggregated according to the INSEE classes also described in Section 2. The intermediate logistics facilities are located in Class 2 municipalities. Fig. 3 represents the cumulative total area of buildings for eight sectors: public services, logistics facilities, agriculture, industry, craft industry facilities, offices, retail and hostel facilities, between 2008 and 2017 in each INSEE class of the Paris region.

Figure 3. Cumulative total area of buildings $\left(\mathrm{m}^{2}\right)$ by economic sector from 2008 to 2017

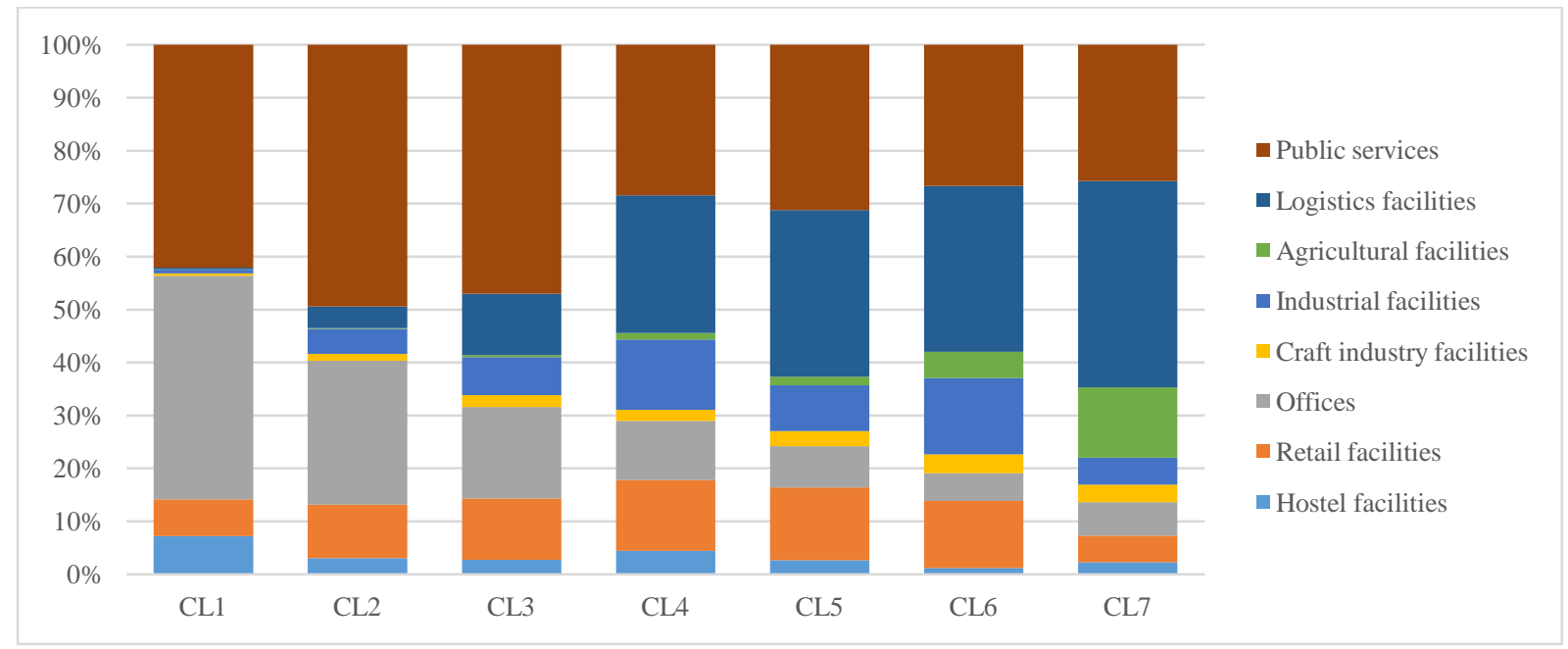

In the Class 1 public services (42\%) and offices (42\%) account for the majority of the construction that took place between 2008 and 2017, and the construction of logistics facilities accounted for only $1 \%$ over the same period. In the suburban municipalities (Classes 3, 4, 5 and 6) offices accounted for a smaller share of the cumulative total area (from $17 \%$ to $5 \%$ ) than in the inner suburbs (Class 2) where they accounted for $27 \%$ of the cumulative total area. In contrast, the construction of logistics facilities was greater in suburban departments than in the departments of the suburbs. For the Class 4,5 and 6 logistics facilities accounted for between $28 \%$ and $38 \%$ of the cumulative total area, whereas in the inner suburbs (Class 2 ) new logistics facilities accounted for $4 \%$ of the cumulative total areas. Hence, little warehouse construction took place in the suburbs where intermediate logistics are overrepresented. With a greater emphasis on the construction of offices, this area is less attractive for new logistics facilities. These figures indicate that 1 ) inner suburbs are less attractive for new logistics development, 2) logistics facilities are difficult to locate in this area. As a result, where there is competition for land logistics is in a disadvantageous position compared with other sectors. Decline is the result of this competition.

The disadvantageous position of logistics can be explained by a reluctance to pay a high price for land. In the inner suburbs, land is precious; land prices are high, and land use high density. Developers prefer to build offices or dense housing than logistics facilities because they have a better rate of return. Estimates provided by real estate developers show that the land price for logistics in the City of Paris (the center of the metropolitan area) is about $8000 € / \mathrm{m} 2$, about $5500 € / \mathrm{m} 2$ in the inner suburbs and 
about $1350 € / \mathrm{m} 2$ in the suburban area (BureauxLocaux, 20206). Land prices are a key factor in the relocation to sub-urban areas for logistics facilities, and explain the lack of competitiveness of the inner suburbs, and by extension intermediate logistics. Our interviews confirmed that some logistics operators prefer to rent new logistics facilities a few kilometers away for a lower price. Many of them prioritized price over proximity to Paris when locating their facility. The drop in the demand for intermediate facilities is to the advantage of other suburban facilities. Land prices in the inner suburbs is a key factor in explaining the decline of intermediate logistics.

We could however ask how urban logistics can be profitable. While land prices are a key factor in the relocation of warehouses to suburban areas, they do not explain the increase in demand of urban logistics. This is a response to reorganization of the supply-chain. Indeed, the rise in small-scale delivery services induces a need for small logistics spaces in dense areas for the transshipments of last-mile parcels. Our interviews gave us some insight into the profitability of urban logistics facilities. In the case of UCCS, the literature showed the main issue to be profitability, which partially explain the difficulties experienced by this model. UCCs were mostly financed by public subsidy because of the land prices. The case of the logistics hostels (Chapelle International) introduced in Paris shows that the combination of logistics and other functions in the same buildings could make the asset profitable. In the case of urban warehouses, for example those developed by Amazon or Ikea, their capacity to invest in warehouses in dense areas where land prices are high can be explained by the size of the company and their financial capacity. As we mentioned before, intermediate logistics facilities are mostly owned by small and independent companies, which do not have the same capacity for investment. Also, both logistics hostels and urban warehouses are multi-level buildings which allow a better rate of return per square meter. Intermediate logistics facilities are older facilities, sometimes with a ridged roof, which does not permit the addition of floors. To intensify land use while maintaining a logistics function existing building should be demolished and new ones constructed. But for the time being the total cost of so doing would be higher than relocation, according to the interviews we conducted with real estate developers. Now the context is not favorable to logistics facilities in the inner suburbs compared with other, more profitable, sectors.

However, given the very recent increase in demand for urban warehouses, the dominant logistics real estate developers in the Paris region such as Prologis, Argan, JLL, BNP Paribas, Segro or Sogaris have adopted a "wait-and-see" attitude; they just have started to consider intermediate logistics as a potential resource to recycle the buildings or the land to develop the urban logistics. Our interviews with logistics real estate developers and municipalities located in the Paris suburbs revealed two positions. Some chose to develop or foster the development activities other than intermediate logistics facilities, thus confirming the results shown previously. But some maintained intermediate logistics facilities, and speculated about the potential development of urban logistics, or stricter regulations favorable to the development of urban logistics.

\subsection{Intermediate logistics facilities: the blind spot of urban logistics policies}

Intermediate logistics facilities are located in a high-value area where the competition for the land with other sectors is not favorable to logistics, mostly because of land prices but also because of the development strategies of companies related to e-commerce business, which constitute the main drivers on the logistics real estate market. There are other factors explaining the rise of urban logistics

\footnotetext{
${ }^{6}$ https://www.bureauxlocaux.com/prix-marche/entrepots
} 
in an area where land prices are high that seems to run contrary to dominant market forces (logistics suburbanization).

Intermediate logistics introduce a third category of logistics facilities, forming a significant part of the logistics real estate market in urban dense areas. However, in terms of urban planning, only one is taken into account by the public authorities today (Debrie \& Heitz, 2017). While largely unknown or ignored, intermediate logistics facilities reveal the complexity involved in the planning and regulation of logistics facilities. The public policy interest in urban logistics involves freight flows in city centers and the urban distribution system. Planning for logistics facilities within the urban fabric is not the main issue, even though this would form one component of planning for a mixed-use compact city. Moreover, public policies are more focused on the innovative nature of urban logistics as shown by the different architectural and urban planning competition e.g. "Réinventer Paris", "Réinventer la Seine" where urban logistics projects have been selected in particular on the basis of their innovative nature. In urban planning, urban logistics is defined as a service that contribute to optimize urban distribution by providing innovative solutions to companies while respecting environ-mental and social conditions (Dablanc, Morganti, et al., 2017; Dablanc, Zeting, et al., 2017).

According to the literature and our interviews, public policy is also a key factor in explaining this trend. By contrast, a lack of direction in public policy could explain a declining trajectory for intermediate logistics. Where there is a lack of strong public policy, significant land speculation can lead to the gradual disappearance of intermediate logistics facilities, to the advantage of other activities. Local public authorities remain major actors in the development of logistics facilities and the type of facilities they authorize (Raimbault, Heitz, \& Dablanc, 2018). For example, at a regional level, the master plan for the lle-de- France region (SDRIF) sets the main guidelines for the location of residential areas, economic activities, and infrastructure. Some of the pro-visions it contains are binding for local urban planning documents. The document institutionalizes the objective of preserving several terminals and focuses on the development of urban logistics or densification of the logistics zones that are associated with transport infrastructure. Inter-mediate logistics facilities remained a blind spot of the regional planning.

The local master plans (at municipality level) do not mention either intermediate logistics. They usually focus on logistics zones without detailed information on what type of activities are located there (Raimbault et al., 2018). Thus, intermediate logistics are taken into account in land use regulations but are not subject to new urban projects or sectorial urban logistics policies. From this point of view, intermediate logistics is not an exception. Most facilities located in economic activity zones (category which encompasses logistics zones) are not well integrated in urban policies. They have received little public investment and are subject to few constraints (architectural, urbanistic) in such a way that these spaces are often perceived as "without interest" the functionalist approach (Lejoux \& Charieau, 2019). Therefore, we observe a double effect at the expense of intermediate logistics. As an activity, it remains invisible to urban policies and it is mainly located in areas that are not subject to any urban logistics policy apart from minimum land use regulation (i.e. granting a building permit). Recently, some public stakeholders have initiated a requalification of these zones in order to open them up to the city and better integrate them into the urban fabric. In this task, the stakeholders' objectives are restricted by their lack of knowledge and data on these activities.

\footnotetext{
${ }^{7}$ In reference to a paper published in Telerama in 2010 by Xavier de Jarcy and Vincent Remy « Comment la France est. devenue moche" (How France became ugly
} 
As a result, intermediate logistics is declining in the Paris region, due to its lack of visibility and dedicated urban logistics policies. Subjected to market developments and the differing strategies of property developers regarding the development of urban logistics, intermediate logistics remains in potential decline. The development of public-private governance for intermediate logistics does not ensure its permanence.

\section{Discussion and conclusion: the process of logistics dualization in metropolitan areas}

This paper has questioned the logistics dualism by identifying a third category: intermediate logistics. Considering the literature review, urban logistics refers to facilities located in dense urban areas and dedicated to urban distribution, whereas suburban facilities are located in low dense areas and dedicated to regional, national or international distribution. Intermediate logistics facilities would be classified as urban logistics regarding the density criterion or suburban logistics regarding origin/destination flows. Our empirical analysis on the Paris Region showed proves that these two criteria are not sufficient to distinguish urban from suburban logistics. Often, suburban logistics facilities plays many roles, and serve at local, national and international scale. On the opposite, facilities located in dense areas such as intermediate logistics facilities are not all dedicated to urban distribution. The freight landscape is more complex and the criteria of density and origin/destination of goods not sufficient to distinguish urban from suburban logistics. Nevertheless, by conducting analyses on intermediate logistics, we observe a declining trajectory. It is probable that it will be displaced by logistics facilities dedicated to last-mile and deliveries. We have noted that the majority of intermediate logistics facilities are located in the suburbs, where new buildings dedicated to new urban services related to the gig economy are also emerging (e.g. dark kitchen, e-commerce facilities for storage or distribution, small depot). Thus, the decline of intermediate logistics would eventually produce a logistics dualism, in which logistics facilities located in dense areas are exclusively dedicated to last-mile delivery. Hence for the time being it seems appropriate to use the term "dualization", making it possible to describe a complex logistics real estate market composed of three segments but undergoing a process that tends to lead to dualism. Our interviews and observations also show that there is no fatalistic necessity concerning the future of intermediate logistics. Their resilience depends on several factors: 1 ) the degree of involvement with and planning by public policy; 2 ) the interests and strategies of logistics land developers who are following the demand of carriers and shippers, and who are increasingly inclined to invest in land located in dense areas due to e-commerce. If this land is already occupied by logistics facilities there is potential for transition to urban logistics; 3 ) the maintenance of small-scale logistics activity focused on wholesale or industrial logistics where there is a continuing interest in being located in dense areas and retaining its property assets.

Intermediate logistics activities can be thought of as a lever that makes it possible to maintain productive activities in suburbs that are still home to working-class people who depend on low-skilled jobs. As the number of manufactures declines, logistics activities offer opportunities for these workers. Intermediate logistics activities can be a means of achieving the objectives of mix-used planning and social diversity policy in areas where working-class are still there. In practical terms, this means to create new regulation to better integrate logistics facilities in a dense urban fabric to limit the conflicts with other activities or neighboring population.

"Dualism" is a well-known concept in geography and urban planning which illustrates the growth of socio-economic inequalities leading to the structuring of two opposing social groups or two opposing areas (i.e. global city vs. other cities; or center and peripheral areas), resulting from the metropolization process (i.e. Sassen, 2001). The evolution of logistics activities in the Paris metropolis 
illustrates a limit of the "dualism" to analyze metropolitan areas, for two reasons. On the one hand, this dual reading, which focuses on urban logistics in city centers and suburban logistics in peripheral areas, ignores the way logistics works, i.e., that urban logistics cannot exist without the network of warehouses located on the outskirts. On the other hand, the opposition of these two spaces tends to make suburbs and the role they continue to play in the metropolitan economy, invisible. Indeed, as we have seen, intermediate logistics are mainly located in the suburbs. These suburbs are undergoing major urban transformations and have been analyzed in terms of deindustrialization and gentrification, highlighting the rise of new tertiary activities (Albecker \& Fol, 2013), which has tended to overlook the industrial, logistics and artisanal activities that have been maintained and that are part of what we might call the "productive economy" (Davezies, 2008). There may be a new narrative to be constructed here on the contribution of the suburbs to the metropolitan productive economy that public policies could seize upon. 


\section{References}

Albecker, M.-F., \& Fol, S. (2013). The restructuring of shrinking surburbs in the Paris Region (dir.). In K. Pallagst, C. MartinezFernandez, \& T. Wiechmann (Eds.), Stories of Tough Times - International Perspectives and Policy Implications in Shrinking Cities, Routledge, New York (pp. 78-98).

Aljohani, K., \& Thompson, R. G. (2016). Impacts of logistics sprawl on the urban environment and logistics: Taxonomy and review of literature. Journal of Transport Geography, 57, 255-263.

Allen, J., Browne, M., \& Cherrett, T. (2012). Investigating relationships between road freight transport, facility location, logistics management and urban form. Journal of Transport Geography, 45-57.

Allen, J., Thorne, G., \& Browne, M. (2007). Practice guide on urban freight. Rijswijk: Bestufs.

Bowen, J. (2008). Moving places: The geography of warehousing in the US. Journal of Transport Geography, 379-387.

Browne, D., \& Ryan, L. (2011). Comparative analysis of evaluation techniques for transport policies. Environmental Impact Assessment Review, 31(3), 226-233.

Browne, M., Sweet, M., Woodburn, A., \& Allen, J. (2005). Urban Freight Consolidation Centres. Final Report.

CBRE. (2020). Real Estate outlook France, Au-delà des marchés en 2020, quels immobiliers à I'horizon 2030 [Online].

Cidell, J. (2010). Concentration and decentralisation: The new geography of freight distribution in US metropolitan areas. Journal of Transport Geography, 18, 363-371.

Cidell, J. (2011). Distribution centers among the rooftops: The global logistics network meets the suburban spatial imaginary. International Journal of Urban and Regional, 4 (35), 832-851.

Dablanc, L. (2018). E-commerce trends and implications for urban logistics. In M. Browne, S. Berhends, J. Holguin-Veras, G. Giuliano, \& J. Woxenius (Eds.), Urban logistics, management policy and innovation in rapidly changing environment. Kogan Page, 392p.

Dablanc, L., Morganti, E., Arvidsson, N., Woxenius, J., \& Browne, M. (2017). The rise of on-demand 'instant deliveries' in European cities. Supply Chain Forum: An International Journal, 2017, 203-217. Kedge Business School. https://doi.org/ 10.1080/16258312.2017.1375375.

Dablanc, L., Zeting, L., De Oliveira, L. K., Klausberg, J., Koning, M., \& Combes, F. (2017). CITYLAB Observatory of Strategic Developments - Deliverable 2.1 - Impacting Urban Logistics. European Commission - Innovation and Networks executive agency - Horizon $\mathrm{H} 2020$.

Davezies, L. (2008). La République et ses territoires : la circulation invisible des richesses, Paris, La République des Idées, Seuil, 110 pages.

Debrie, J., \& Heitz, A. (2017). La question logistique dans l'aménagement de l'lle-de- France : formulation d'un enjeu métropolitain versus absence de concrétisation dans les projets urbains ? Géographie, Economie, Société, 19(2017), 55-73.

Decoupage morphologique d'Ile-de-France 2014: https://www.data.gouv.fr/fr/datasets/ decoupage-morphologique-de-l-ilede-france-idf/.

Diziain, D., Rippert, C., \& Dablanc, L. (2012). How can we bring logistics back into cities? The case of Paris Metropolitan Area. Procedia - Social and Behavioral Sciences, 267-281.

DTZ. (2011). 1998-2008-2011: Evolution de l'immobilier logistique.

Fender, M., \& Fender, B. (2015). Les actifs l'immobiliers logistiques, approches opérationnelle, techniques et financière intégrées. Dunod.

Giuliano, G., \& Kang, S. (2018). Spatial dynamics of the logistics industry: Evidence from California. Journal of Transport Geography, 66, 248-258. January 2018.

Heitz, A. (2017). La Métropole Logistique: structure métropolitaine et enjeux d'aménagement. Thèse de doctorat. Université Paris-Est (Gustave Eiffel). https://www.theses.fr/201 7PESC1098.

Heitz, A., Launay, P., \& Beziat, A. (2017). Rethinking data collection on logistics facilities: New approach for measuring the location of warehouses and terminals in metropolitan areas. Transportation Research Record: Journal of the Transportation Research Board, No. 2609.

Heitz, A., Launay, P., \& Beziat, A. (2018). Heterogeneity of logistics facilities: An issue for a better understanding and planning of the location of logistics facilities. European Transport Research Review, 11, 5.

Hesse, M. (2002). Shipping news: The implications of electronic commerce for logistics and freight transport. Ressources, Conservation and Recycling, 36(3), 211-240.

Hesse, M. (2004). Logistics and freight transport policy in urban areas: A case study of Berlin-Brandenburg/Germany. European Planning Studies, 12(7), 1035-1053.

Hesse, M. (2008). The City as terminal. In Logistics and freight distribution in an urban context, 2008. Ashgate publishing.

Hesse, M., \& Rodrigue, J. (2004). The transport geography of logistics and freight distribution. Journal of Transport Geography, 3(12), 171-184.

JLL. (2019). French logistics market overview, Report H1 2019.

Kin, B., Verlinde, S., van Lier, T., \& Macharis, C. (2015). Is there life after subsidy for an urban consolidation centre? An investigation of the total costs and benefits of a privately-initiated concept. Transportation Research Procedia, 12(2016), 357369.

Leigh, N. G., \& Hoelger, N. Z. (2012). Smart growth\&apos;s blind side, sustainable cities need productive urban industrial land. Journal of the American Planning Association, 78, 87-103.

Lejoux, P., \& Charieau, C. (2019). La zone d'activité économique : objet urbain non identifié ? (Economic activity zone: an unidentified urban object?) [Online] Territoire en Mouvement, 43, 2019, published November 6th 2019. 
Leonardi, J., Browne, M., \& Allen, J. (2012). Before-after assessment of a logistics trial with clean urban freight vehicles: A case study in London. Procedia - Social and Behavioral Sciences, 39, 146-157.

Marcucci, E., \& Danielis, R. (2007). The potential demand for a urban freight consolidation centre. Transportation, 35(2), 269284.

Masson, S., \& Petiot, R. (2012). Attractivité territoriale, infrastructures logistiques et développement durable ». In les Cahiers Scientifiques du Transport (pp. 63-90).

Merenne-Schoumaker, B. (2011). La localisation des industries, Enjeux et dynamiques. Rennes: Presse Universitaire de Rennes.

Nappi-Choulet, I., Maleyre, I., \& Maury, T. (2007). Un modèle hédonique des prix de bureaux `a Paris et en petite couronne. Revue d'économie régionale et urbaine, (3), 421-451.

Olsson, J., \& Woxenius, J. (2014). Localisation of freight consolidation centers serving small road hauliers in a wider urban area: Barriers for more efficient freight deliveries in Gothenburg. Journal of Transport Geography, 34, 25-33. R.

Jin D. Simchi-Levi L Wang X Wang S. Yang, (2019) Shrinking the upper confidence bound: A dynamic product selection problem for urban warehouses, SSRN, 33p, Available at SSRN:https://ssrn.com/abstract=3591281

Raimbault, N. (2014). Gouverner le développement logistique de la métropole : périurbanisation, planification et compétition métropolitaines. PhD Thesis. University of Paris Est [In French].

Raimbault, N., Heitz, A., \& Dablanc, L. (2018). Urban planning policies for logistics facilities: a comparison between US metropolitan areas and the Paris region. In M. Browne, S. Berhends, J. Holguin-Veras, G. Giuliano, \& J. Woxenius (Eds.), Urban logistics, management policy and innovation in rapidly changing environment. Kogan Page, 392p.

Rakotonarivo, D., \& Dablanc, L. (2010). The impacts of logistics sprawl: How does the location of parcel transport terminals affect the energy efficiency of goods' movements in Paris and what can we do about it? Procedia-Social and Behavioral Sciences, 2(3), 6087-6096.

Rodrigue, J.-P., \& Berhends, S. (2018). Dualism of urban freight distribution. In M. Browne, S. Berhends, J. Holguin-Veras, G. Giuliano, \& J. Woxenius (Eds.), Urban logistics, management policy and innovation in rapidly changing environment. Kogan Page, 392p.

Rodrigue, J.-P., Dablanc, L., \& Giuliano, G. (2017). (2017) the freight landscape: convergence and divergence in urban freight distribution. Journal of Transport and Land Use, 10(1), 557-572. https://doi.org/10.5198/jtlu.2016.869.

Sakai, T., Beziat, A., \& Heitz, A. (May 2020). (2020) location factors for logistics facilities: Location choice modeling considering activity categories. Journal of Transport Geography, 85, Article 102710.

Sassen, S. (2001). The global city (1`ere'ed.) (1`ere'ed.,. 1991. New York, London, Tokyo, Princeton: Princeton University Press, $447 \mathrm{p}$.

Sitadel database 2015: http://developpement-durable.bsocom.fr/statistiques/ReportFol ders/reportFolders.aspx.

Strale, M. (2013). La logistique : localisation des activités et impacts territoriaux, thèse de doctorat : géographie. Université Libre de Bruxelles.

Taniguchi, E., Thompson, R., \& Yamada, T. (1999). Modelling city logistics. In E. Taniguchi, \& R. G. Thompson (Eds.), City Logistics I, 1st International Conference on City Logistics. Institute of Systems Science Research.

Trentini, A., Gonzalez Feliu, J., \& Malhéné, N. (2015). Developing Urban Logistics Spaces: UCC and PLS in South-Western Europe. 